\title{
RESULTS OF $\mathrm{SO}_{2}, \mathrm{NO}_{\mathrm{x}}$, AND CO MONITORING AT MCMURDO STATION, ANTARCTICA
}

\author{
by
}

Robert M. Lugar

EG\&G Idaho, Inc.

Environmental Technology Unit

Idaho Falls, ID 83415-1406

May 1993

Interagency Agreement No. DPP-9102787
with

U.S. Department of Energy

Idaho Falls Operations Office

Idaho Falls, ID 83402

\section{Project Officer}

Dr. Sidney Draggan

Environmental Officer

Office of Polar Programs

National Science Foundation

Washington, DC 20550 


\section{DISCLAIMER}

Portions of this document may be illegible in electronic image products. Images are produced from the best available original document. 


\begin{abstract}
This report presents the results of ambient air monitoring of carbon monoxide (CO), sulfur dioxide $\left(\mathrm{SO}_{2}\right)$, nitric oxide $(\mathrm{NO})$, nitrogen dioxide $\left(\mathrm{NO}_{2}\right)$, and total oxides of nitrogen $\left(\mathrm{NO}_{\mathrm{x}}\right)$ performed during the final weeks of the 1992-1993 austral summer in the vicinity of McMurdo Station, Antarctica. Commercially available, high sensitivity ambient air gas analyzers were used to continuously measure gas concentrations at two locations over a two and a three week time period respectively. Sampling site selection, sampling procedures and quality assurance procedures used for this effort were consistent with U.S Environmental Protection Agency guidelines for local ambient air quality networks. $\mathrm{CO}, \mathrm{SO}_{2}$, and $\mathrm{NO}_{2}$ concentrations measured were below the associated U.S. National Ambient Air Quality Standards. Carbon monoxide levels measured at both locations were near or below the instrument detection limit of 0.1 part per million (ppm). Hourly average $\mathrm{SO}_{2}$ concentrations ranged from below the detection limit of 1 part per billion (ppb) to a single maximum hourly average value of $60 \mathrm{ppb}$. Hourly average $\mathrm{NO}_{2}$ concentrations ranged from below the detection limit of $1 \mathrm{ppb}$ to a single maximum hourly average value of $26 \mathrm{ppb}$. The impact on local air quality of ships docked at an ice pier was observed and quantified. The initial baseline effort demonstrated that site selection and sampling equipment performance were satisfactory, and provided useful data for assessing the impact of McMurdo operations on the local ambient air quality.
\end{abstract}

\title{
DISCLAIMER
}

This report was prepared as an account of work sponsored by an agency of the United States This report Government nor any agency thereof, nor any of their Government. Neither the Unity, express or implied, or assumes any legal liability or responsiemployees, makes any wartion, or bility for the accuracy, completeness, or usefulness of any ining privately owned rights. Referprocess disclosed, or represents that its use would not inforice service by trade name, trademark, ence herein to any specific commercial product, process, or service by its endorsement, recommanufacturer, or otherwise does not necessarily constitute or imply its encoreof. The views mendation, or favoring by the United States Government or any agency the rect those of the and opinions of authors expressed herein do not 


\section{RESULTS OF $\mathrm{SO}_{2}, \mathrm{NO}_{x}$, AND CO MONITORING AT MCMURDO STATION, ANTARCTICA}

\section{Introduction}

McMurdo Station $\left(77^{\circ} 51^{\prime}\right.$ South $166^{\circ} 40^{\prime}$ East) is the largest human community in Antarctica. It is a coastal station constructed on low ash and volcanic hills at the southern tip of Ross Island. McMurdo serves as the primary logistics and staging facility for airborne resupply of inland research stations and supports a wide variety of scientific research. The austral winter (March-September) population in 1992 was 257, and the austral summer (October-February) population exceeded 1,100. The station consists of over 100 structures, and numerous equipment laydown and storage areas. A nearby skiway airport and sea-ice runway serve fixed wing aircraft for flights to the Antarctica mainland, as well as flights to and from New Zealand. Emissions of atmospheric pollutants at or near McMurdo result from a variety of sources, including: boilers, furnaces, space heaters, electric generators, motor vehicle engines, incinerator, fugitive dust, petroleum storage tank vapors, aircraft operations, and ships. The major fixed air emission source is believed to be the electric generation plant. Tables 1 and 2 summarize the major source categories and estimated air pollutant/products of combustion emissions at McMurdo. There is also conjecture that Mt. Erebus, an active volcano located approximately 14 kilometers northeast of McMurdo, may contribute to local ambient air pollutant levels; the available meteorological data and elevation difference, however, suggest there is no continual, direct influence from Mt. Erebus on the ambient air quality at McMurdo' ${ }^{1}$ Effects of Mt. Erebus emissions have been observed in snow around Ross Island, and the $\mathrm{SO}_{2}$ emissions from the volcano have been measured, therefore there is a possibility of occasional direct effects and effects from atmospheric recirculation.

A report on the National Science Foundation (NSF) implementation of a strategy to comply with environmental law in Antarctica (NSF 1989) established the need to assess the environmental impact of air emissions at McMurdo Station and other U.S. Stations. In addition, the recent Protocol on Environmental Protection to the Antarctic Treaty (NSF 1991) and implementation of interim incineration of selected solid wastes at McMurdo further underlined the need to implement an ambient air monitoring network. Incineration at McMurdo ceased on March 22, 1993. In 1992 an ambient air monitoring plan for Mcmurdo was prepared that established the objectives of the monitoring effort as: (1) to determine the highest concentrations of pollutants expected to occur in the area covered by the network, (2) to determine representative concentrations of selected air pollutants in areas of high population density (3) to determine the impact on ambient pollution levels of significant sources or source categories, and (4) to determine background levels of selected air pollutants (Lugar, 1992).

The objectives and performance criteria established for the monitoring network were consistent with the intent of U.S. EPA State and Local Air Monitoring Stations (SLAMS) objectives and network design (40CFR58, Appendix D). Quality assurance and quality control aspects of the monitoring effort were generally consistent with U.S. EPA sampling procedures, and the U.S. EPA Quality Assurance Handbook (US EPA 1977).

1 Personal communication with Charles R. Stearns, Department of Atmospheric and Oceanic Sciences, Univ. of Wisconsin, Madison, WI, September 12, 1991. 
Table 1. Comparison of Sources of Products of Combustion at McMurdo Station (thousands of pounds per year)

\begin{tabular}{|c|c|c|c|c|c|c|}
\hline $\begin{array}{r}\text { Compound } \\
\text { Discharged }\end{array}$ & $\begin{array}{c}\text { Electric } \\
\text { Generation } \\
\end{array}$ & $\begin{array}{c}\text { Water } \\
\text { Distribution }\end{array}$ & $\begin{array}{l}\text { Space } \\
\text { Heating }\end{array}$ & $\begin{array}{l}\text { Surface } \\
\text { Vehicles }\end{array}$ & $\begin{array}{c}\text { Waste } \\
\text { Incineration }^{1}\end{array}$ & TOTAL \\
\hline $\mathrm{CO}_{2}$ & 27207 & 14867 & 4460 & 6311 & 444 & 53291 \\
\hline $\mathrm{H}_{2} \mathrm{O}$ & 9069 & 5775 & 1732 & 2478 & 414 & 19468 \\
\hline $\mathrm{SO}_{2}$ & 17.1 & 9.5 & 2.9 & 0.14 & 0.19 & 29.8 \\
\hline $\mathrm{NO}_{\mathrm{x}}$ & 111.6 & 9.3 & 2.8 & 15.2 & 0.27 & 39.2 \\
\hline Part./HC & 10.6 & 2.6 & 1.4 & 11.2 & 0.015 & 25.1 \\
\hline $\mathrm{HCl}$ & $<1.0$ & $<0.5$ & $<0.1$ & $<0.01$ & 0.088 & $<1.6$ \\
\hline
\end{tabular}

\section{1. after scrubber}

Source: Pearson 1991. 
Table 2. Estimated Annual Air Pollutant Emissions at McMurdo Station

\begin{tabular}{|c|c|c|c|c|c|c|c|}
\hline \multirow[b]{2}{*}{ Source Category } & \multicolumn{2}{|c|}{ Annual Emission Basis } & \multicolumn{5}{|c|}{ Pollutant Emission Rate (tons $\mathrm{s}^{\mathrm{a}} / \mathrm{yr}$ ) } \\
\hline & Units & Quantity & $\mathrm{SO}_{2}$ & $\mathrm{NO}_{2}$ & PM-10 & $\mathrm{HC}$ & $\mathrm{CO}$ \\
\hline \multicolumn{8}{|l|}{ Aircraft Operations } \\
\hline LC -130 and C-130 & LTOs $^{b}$ & 328 & 0.6 & 2.9 & 0.4 & 8.9 & 14.0 \\
\hline C-141 & LTOs & 25 & 0.004 & 0.2 & 0.01 & 1.8 & 2.2 \\
\hline $\mathrm{C}-5 \mathrm{~B}$ & LTOs & $5^{\mathrm{c}}$ & 0.001 & 0.1 & neg. & 0.2 & 0.5 \\
\hline Subtotal & & & 0.7 & 3.2 & 0.4 & 11.0 & 17.0 \\
\hline \multicolumn{8}{|l|}{ Internal combustion engines } \\
\hline Diesel (stationary and mobile) & $1000 \mathrm{gal}^{\mathrm{d}}$ & 1500 & 23.0 & 350.0 & 25.0 & 28.0 & 77.0 \\
\hline Gasoline (mobile) & $1000 \mathrm{gal}$ & 150 & 0.4 & 7.7 & 0.5 & $15.0^{\mathrm{e}}$ & 300.0 \\
\hline \multicolumn{8}{|l|}{ External combustion } \\
\hline Boilers, furnaces, etc. & $1000 \mathrm{gal}$ & 1300 & 4.6 & 13.0 & $1.6^{f}$ & $1.6^{\mathrm{f}}$ & 3.3 \\
\hline Open burning (landfill) & \multicolumn{2}{|c|}{ DISCONTINUED } & 0 & 0 & 0 & 0 & 0 \\
\hline \multicolumn{8}{|l|}{ Storage tanks (evaporation) } \\
\hline JP-8 & & & & & & 0.2 & \\
\hline Gasoline & & & & & & 7.2 & \\
\hline TOTAL McMurdo & & & 29 & 374 & 28 & 63 & 398 \\
\hline
\end{tabular}

a. One ton equals 0.907 metric tons. English units are used in this table because regulatory emission limits and U.S. EPA emission factors are given in English units.

b. $\quad$ Landing take-off cycles.

c. Only two C-5B flights to McMUrdo were reported for the 1989-90 summer season, but up to five flights per season would be typical.

d. One gallon equals 3.785 liters.

e. Sum of exhaust, evaporative, and crankcase emissions.

f. Used emission factors from residential furnaces.

Source: NSF 1991. 


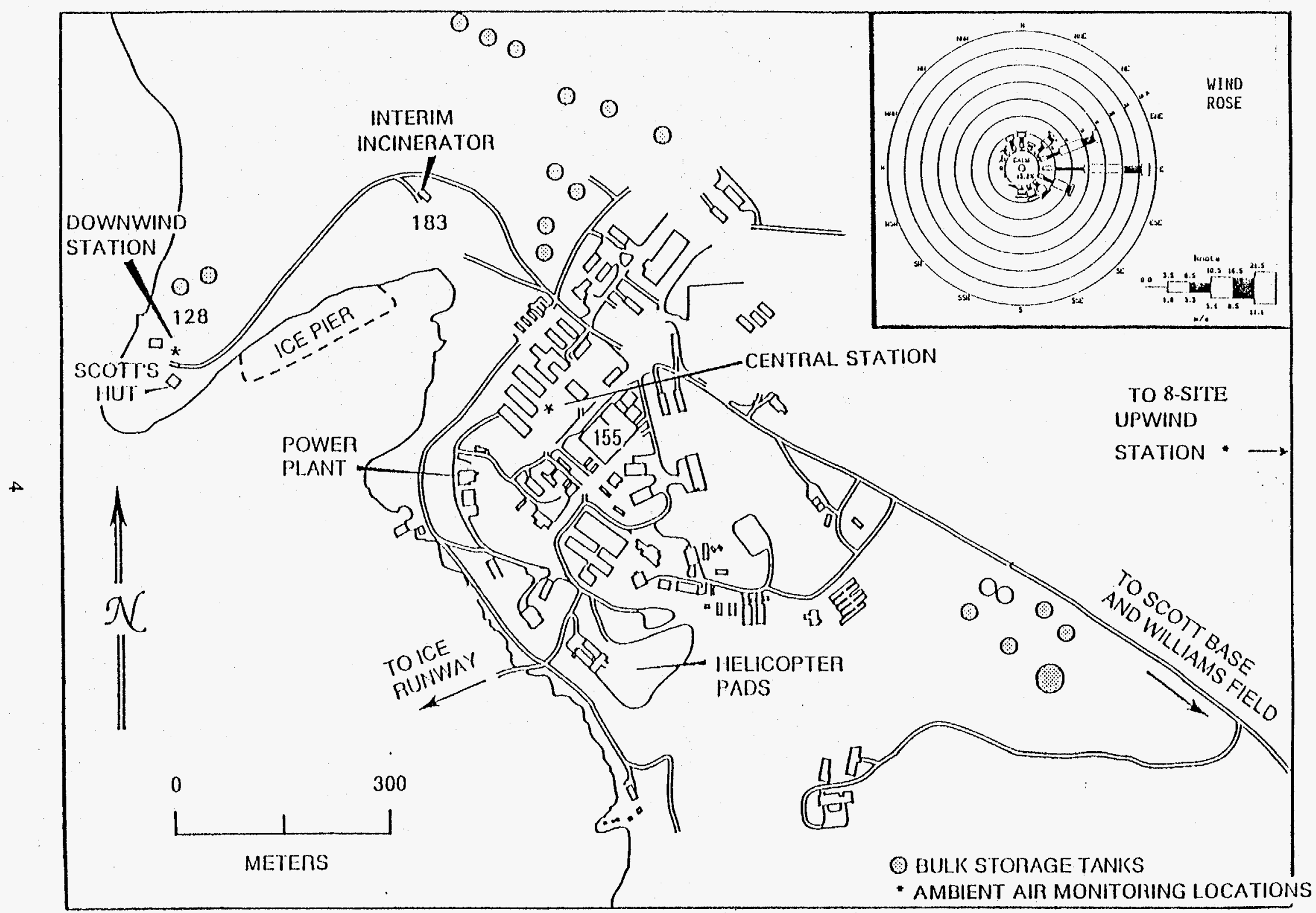

Figure 1. Map of Ambient Air Monitoring Stations at McMurdo, Antarctica. 
A variety of air pollutants, including many for which the U.S. EPA has established National Ambient Air Quality Standards, were selected for monitoring. Gaseous air pollutants selected for this baseline monitoring included sulfur dioxide $\left(\mathrm{SO}_{2}\right)$, nitrogen oxides $\left(\mathrm{NO} / \mathrm{NO}_{2} / \mathrm{NO}_{\mathrm{x}}\right)$, and carbon monoxide (CO). Utilizing historical wind data, a sampling network consisting of three locations was selected for the gas monitoring. The locations were selected after field reconnaissance and were based on the objectives outlined in the monitoring plan, the availability of electrical power and other operational support, and location of major emission sources. The three sites selected were: 8-Site for the predominantly upwind location, Hut Point for the predominantly downwind site, and Central McMurdo, near building 155, as the "worst case urban" location (See Figure 1). The monitoring plan called for one set of continuous gas analyzers to be permanently located at Hut Point, and a second set of analyzers to be rotated on a biweekly basis between the Central McMurdo and 8-Site locations.

\section{Methods}

Each set of gas analyzers was housed in an insulated, temperature controlled weather shelter. The weather shelters provided the necessary room-temperature operating environment for the analyzers, and were designed to keep the internal shelter temperature as stable as possible, thereby optimizing the analyzer measurement stability. Each shelter also contained a zero air supply, gas calibration system, datalogger, calibration gas cylinders, electrical outlets, and internal lighting. Electricity (110 $\mathrm{VAC}$ ) was provided to each shelter from nearby power lines. Due to the potential for unstable line power and occasional outages, each shelter also included a power sifter, two uninterrupted power supplies (UPS), and two surge protectors to minimize data loss and protect the monitoring system from damage. Each analyzer utilized a nominal $6.4 \mathrm{~mm}$ ID Teflon ${ }^{\mathrm{TW}}$ tubing for a sample inlet line and a $47 \mathrm{~mm}$ diameter Teflon ${ }^{\mathrm{Th}}$ inlet particulate filter. Each shelter had a single roof penetration for an inverted U-shaped PVC pipe assembly that housed a bundle of three inlet lines and provided protection of the inlet tube openings from blowing snow and dust.

The gas analyzers, gas calibration systems, and zero air supplies were manufactured by Thermo Environmental Inc. All analyzers were calibrated using a Matheson NBS traceable certified gas standard, a Model 111 Zero Air Supply, and Model 146 Gas Calibration System. Multipoint calibration curves were prepared for all instruments during start-up of the monitoring program, and again just prior to the conclusion of the monitoring period. Additional zero and span checks were performed periodically. Additionally, a recalibration was performed once on the Hut Point analyzers during the three-week operating period.

$\mathrm{SO}_{2}$ was continuously monitored using a Model $43 \mathrm{~S}$ High Sensitivity Pulsed Fluorescence $\mathrm{SO}_{2}$ Analyzer. Although this instrument does not have a U.S. EPA designation as a compliance monitor, it is identical to the EPA designated Model 43A in most respects (U.S. EPA Equivalent Method to 40CFR50 Appendix A). The principal difference in the Model 43S is its improved sensitivity (lower detectable limit of $0.1 \mathrm{ppb} \mathrm{SO}_{2}$ ), and associated lower operating ranges (minimum range of $10 \mathrm{ppb}$, maximum range of $200 \mathrm{ppb}$ ). The Model $43 \mathrm{~S}$ was selected because the ambient $\mathrm{SO}_{2}$ levels at McMurdo were suspected to be in the ppb range or lower.

$\mathrm{NO} / \mathrm{NO}_{2} / \mathrm{NO}_{\mathrm{x}}$ was continuously measured using a Model $42 \mathrm{~S}$ Chemiluminescence Low Level NO$\mathrm{NO}_{2}-\mathrm{NO}_{x}$ Analyzer. This instrument does not have a U.S. EPA designation as a reference method monitor, however it is very similar to the EPA designated Model 42; the main difference being the 
improved sensitivity of the Model $42 \mathrm{~S}$ (minimum detectable limit of 50 parts per trillion). Data was collected in accordance with U.S. EPA Reference Method described in 40CFR50 Appendix F.

CO was measured continuously using a Model 48 Gas Filter Correlation (GFC) Ambient CO Analyzer. This instrument is designated by the U.S. EPA as a Reference Method (40CFR50 Appendix C), and holds designation reference method number RFCA-0981-054. It is not available in a more sensitive model as are the $\mathrm{SO}_{2}$ and $\mathrm{NO}_{x}$ analyzers, and has a minimum detectable limit of 0.1 parts per million (ppm).

The datalogger used in each shelter was an Environmental Systems Corporation ESC 8800 Data Logger, programmed to perform hourly averaging and storage of the analyzer outputs. In addition, a multichannel chart recorder was used in each shelter to provide additional real-time record of the analyzer output during calibration, span and zero checks, and initial operation.

Due to delays in equipment procurement and delivery, the gas analyzers arrived at McMurdo late in the summer season, and were operated for a limited time. The Hut Point analyzers were placed into continuous operation between 23JAN93 and 25JAN93, and ran approximately three weeks until shutdown on 16FEB93 and 17FEB93. The Central McMurdo/8-Site set of analyzers were only operated at the Central McMurdo location due to time constraints. The Central McMurdo analyzers were placed into continuous operation between 30JAN93 and 01FEB93, and ran approximately two weeks until their shutdown on 17FEB93.

\section{Results}

The concentrations of $\mathrm{SO}_{2}, \mathrm{NO}_{2}$, and $\mathrm{CO}$ measured in the McMurdo locale during this initial monitoring effort were below all applicable U.S. National Ambient Air Quality Standards (NAAQS). $\mathrm{SO}_{2}, \mathrm{NO}, \mathrm{NO}_{2}$ and $\mathrm{NO}_{\mathrm{x}}$ were continuously measured at both Hut Point and Central McMurdo in the low parts per billion (ppb) concentration range. CO levels at both locations were near or below the $0.1 \mathrm{ppm}$ level of detection. The localized impact of vehicle and ship emissions on the ambient concentration of $\mathrm{SO}_{2}$ and $\mathrm{NO}_{x}$ were observed at Hut Point. No prominent evidence of any direct effect of $\mathrm{SO}_{2}$ emissions from Mt. Erebus were observed during this initial monitoring effort. Table 3 provides a summary of the Central McMurdo and Hut Point average hourly gas concentration data and associated NAAQS for the gaseous air pollutants measured. A graphical presentation of hourly average concentration of $\mathrm{CO}, \mathrm{SO}_{2}, \mathrm{NO}_{2}, \mathrm{NO}$, and $\mathrm{NO}_{x}$ measured at Central McMurdo and Hut Point are provided on Figures 2 through 11 . Note that the data presented on these figures has been screened to remove data associated with analyzer calibration, analyzer or datalogger downtime or malfunction, and any other conditions resulting in erroneous or suspect data. Ambient gas concentrations were measured only at Hut Point and Central McMurdo locations. The planned alternating of the shelter and instruments between Central McMurdo and the predominantly upwind 8site was canceled due to time constraints.

The localized impact of ship emissions and cargo handling activities at the ice pier were observed at Hut Point from analysis of wind direction, continuous concentration measurements (chart recorder output), and hourly average concentration data for $\mathrm{NO}_{x}$ gases and $\mathrm{SO}_{2}$. During the time period when the Research Vessel (R/V) Akademik Federov was docked at the ice pier the average $\mathrm{NO}_{2}$ concentration at Hut Point was $5.6 \mathrm{ppb}$. After the departure of the R/V Akademik Federov, the 
Figure 2.

Central McMurdo Hourly Avg. CO Concentration

McMurdo, Antarctica 30JAN93 - 17FEB93

U.S. NAAQS, $10 \mathrm{mg} / \mathrm{m} 3(8.7 \mathrm{ppm}) 8$-hour average not to be exceeded $>1 /$ year

10

8

2$$
-2
$$

30JAN O1FEB O3FEB OSFEB O7FEB O9FEB 11FEB 13FEB 15FEB 
Figure 3.

Central McMurdo Hourly Avg. SO2 Concentration McMurdo, Antarctica 01FEB93 - 17FEB93

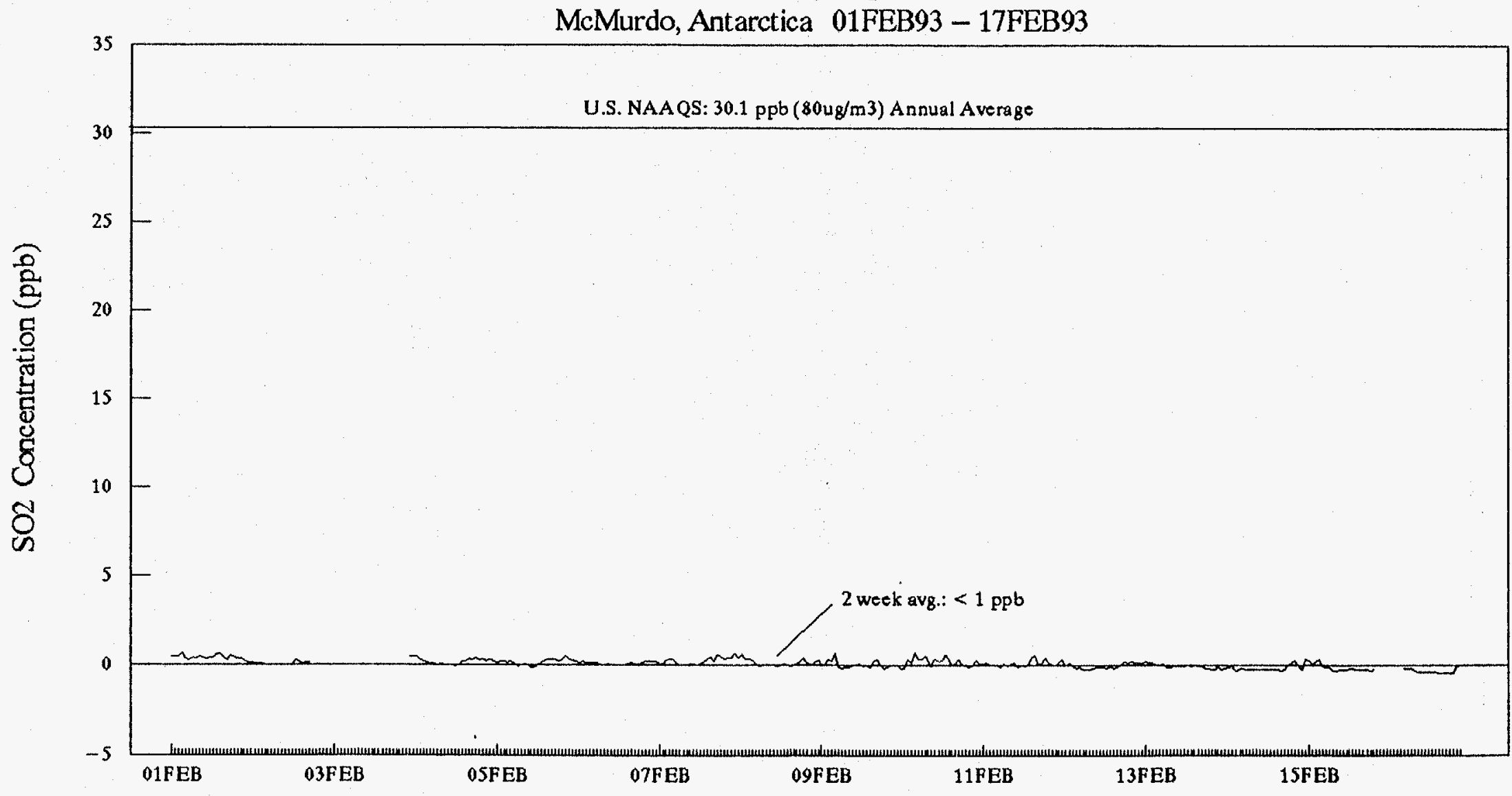




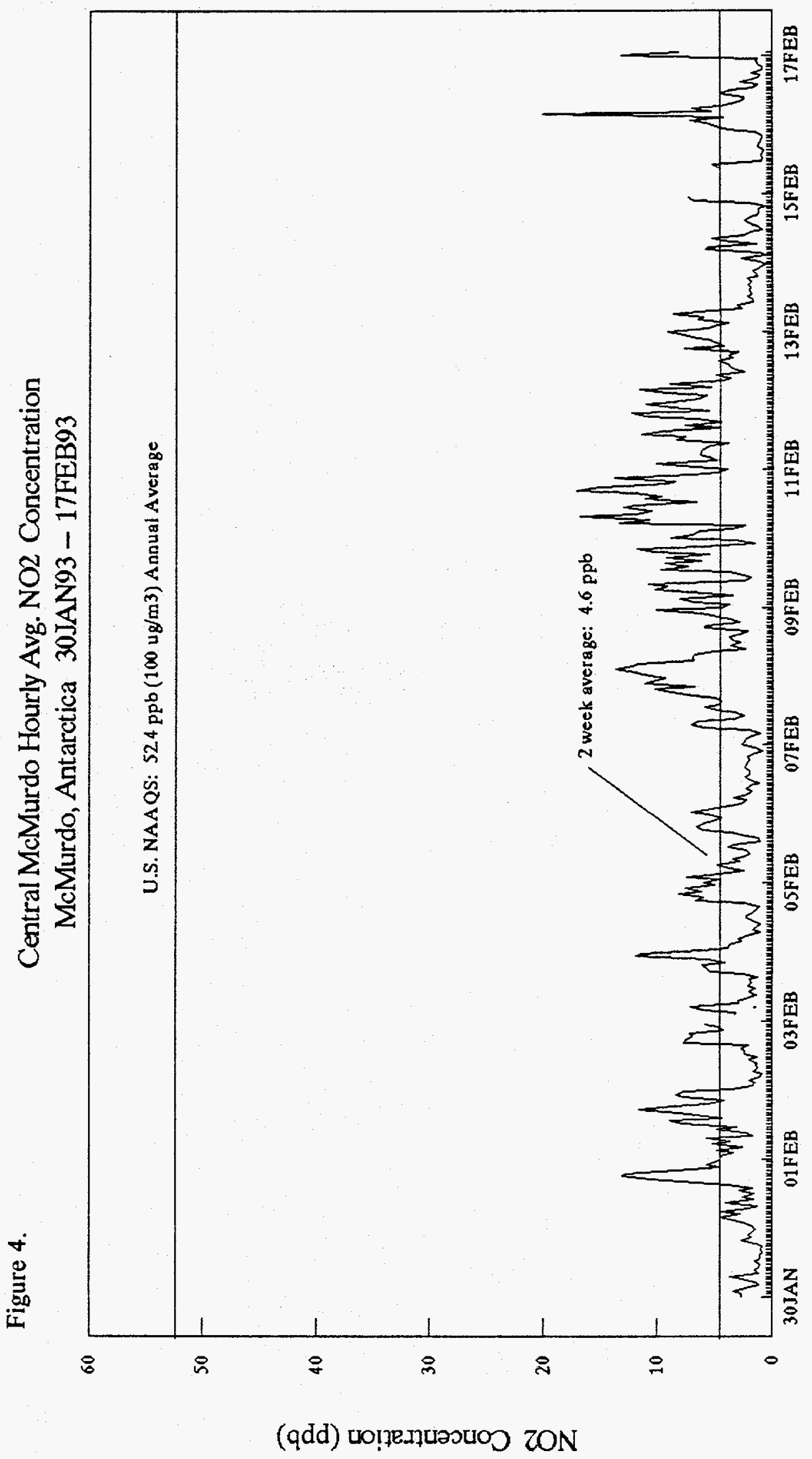




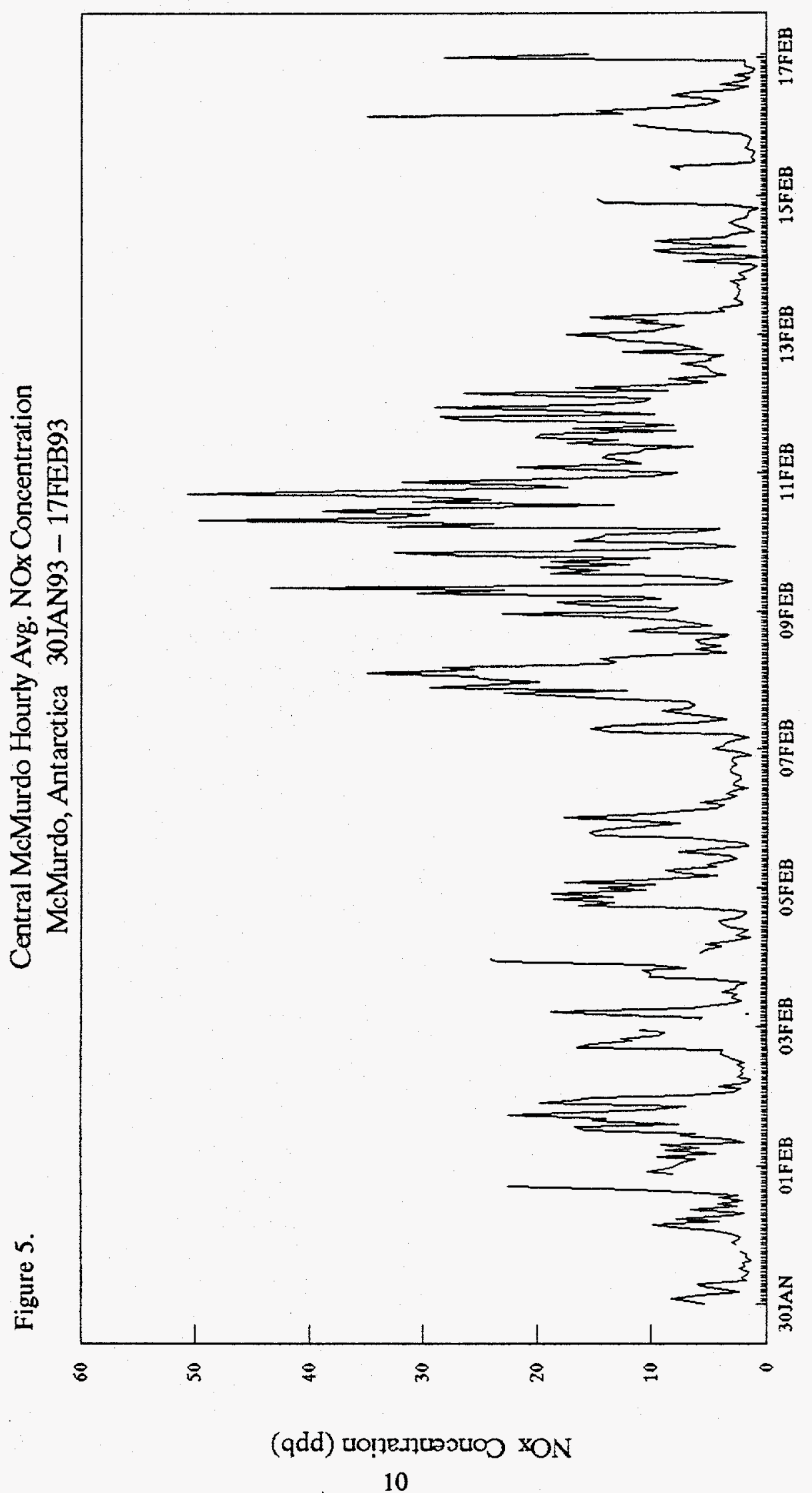


Figure 6.

Hut Point Hourly Average CO Concentration

McMurdo, Antarctica 23JAN93 - 17FEB93

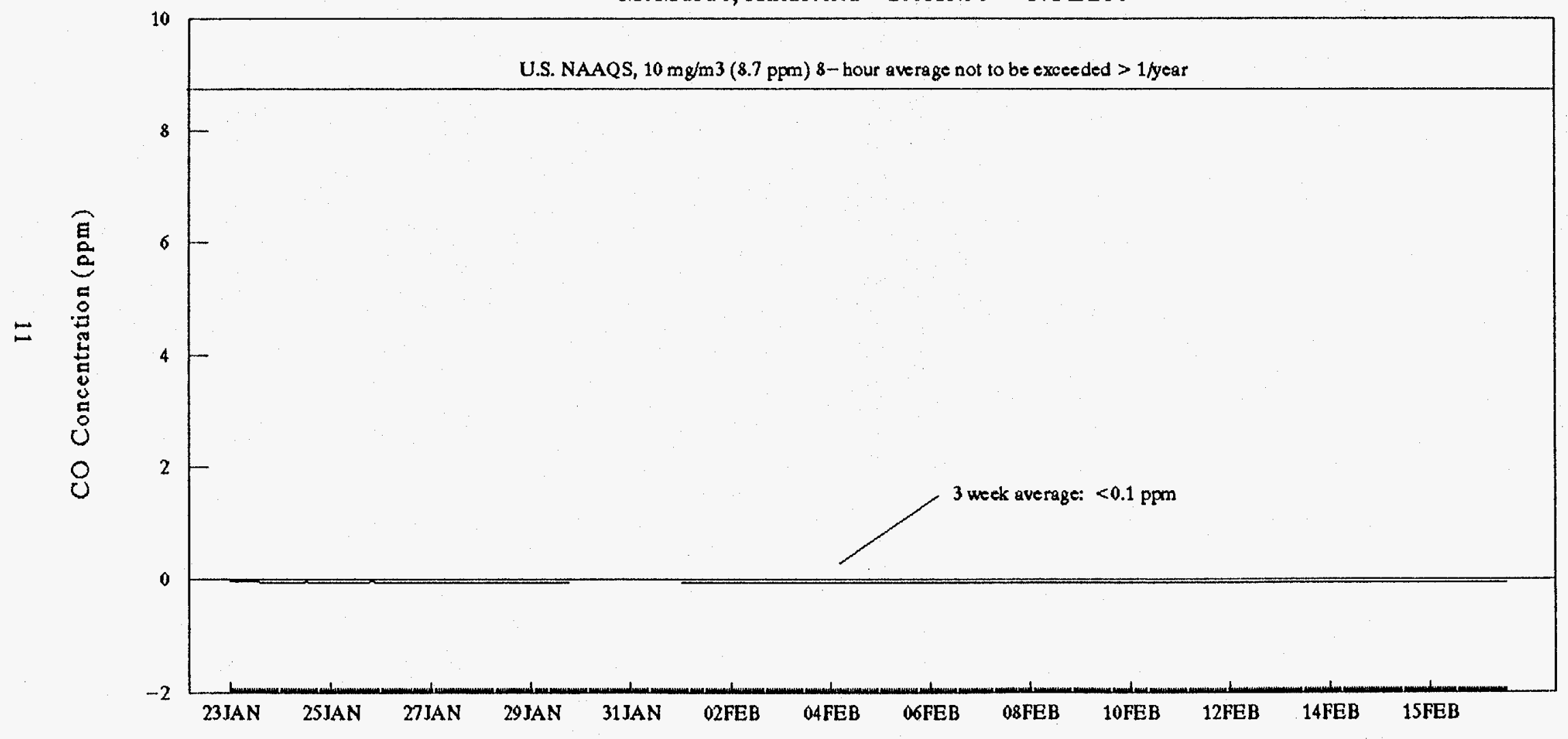




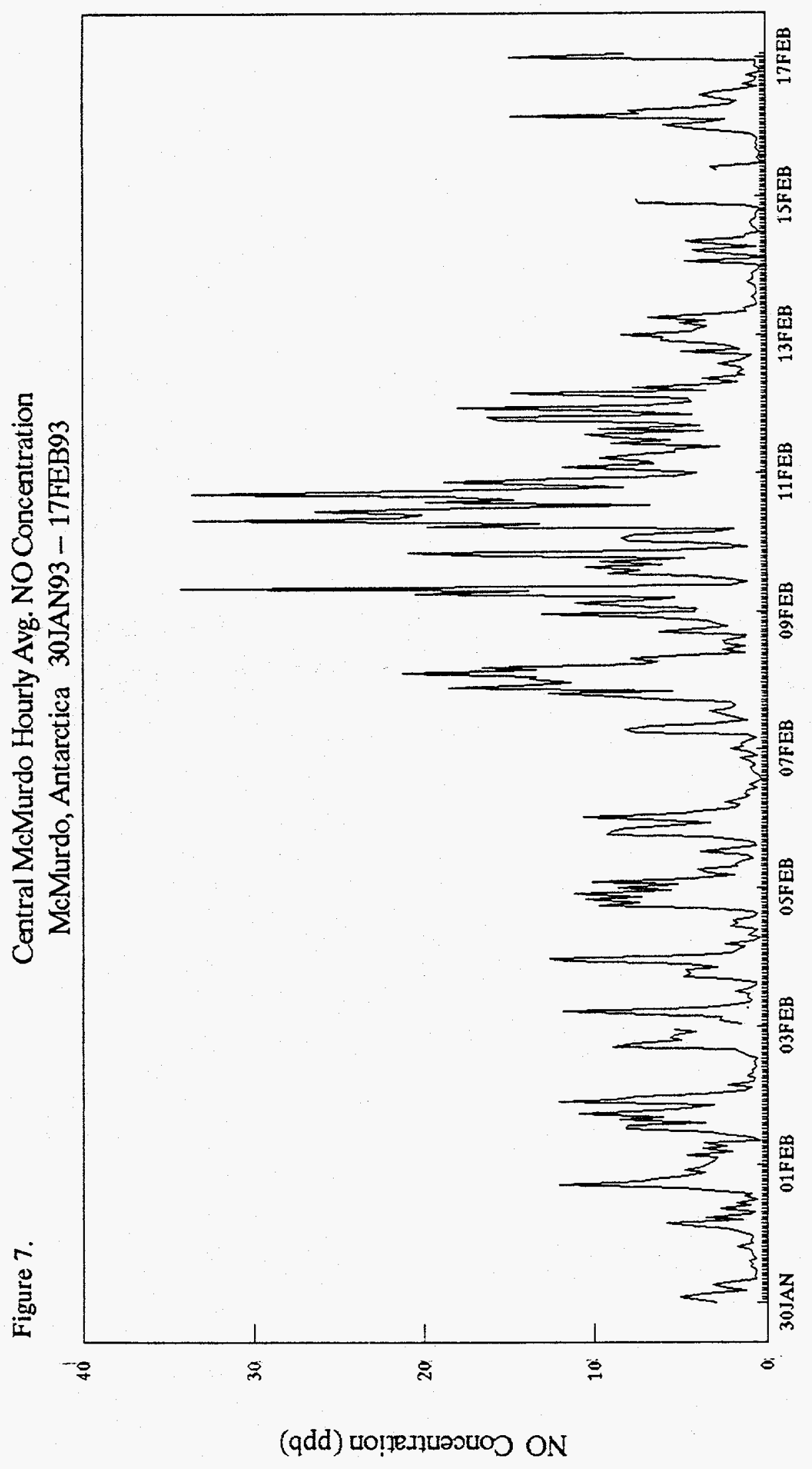




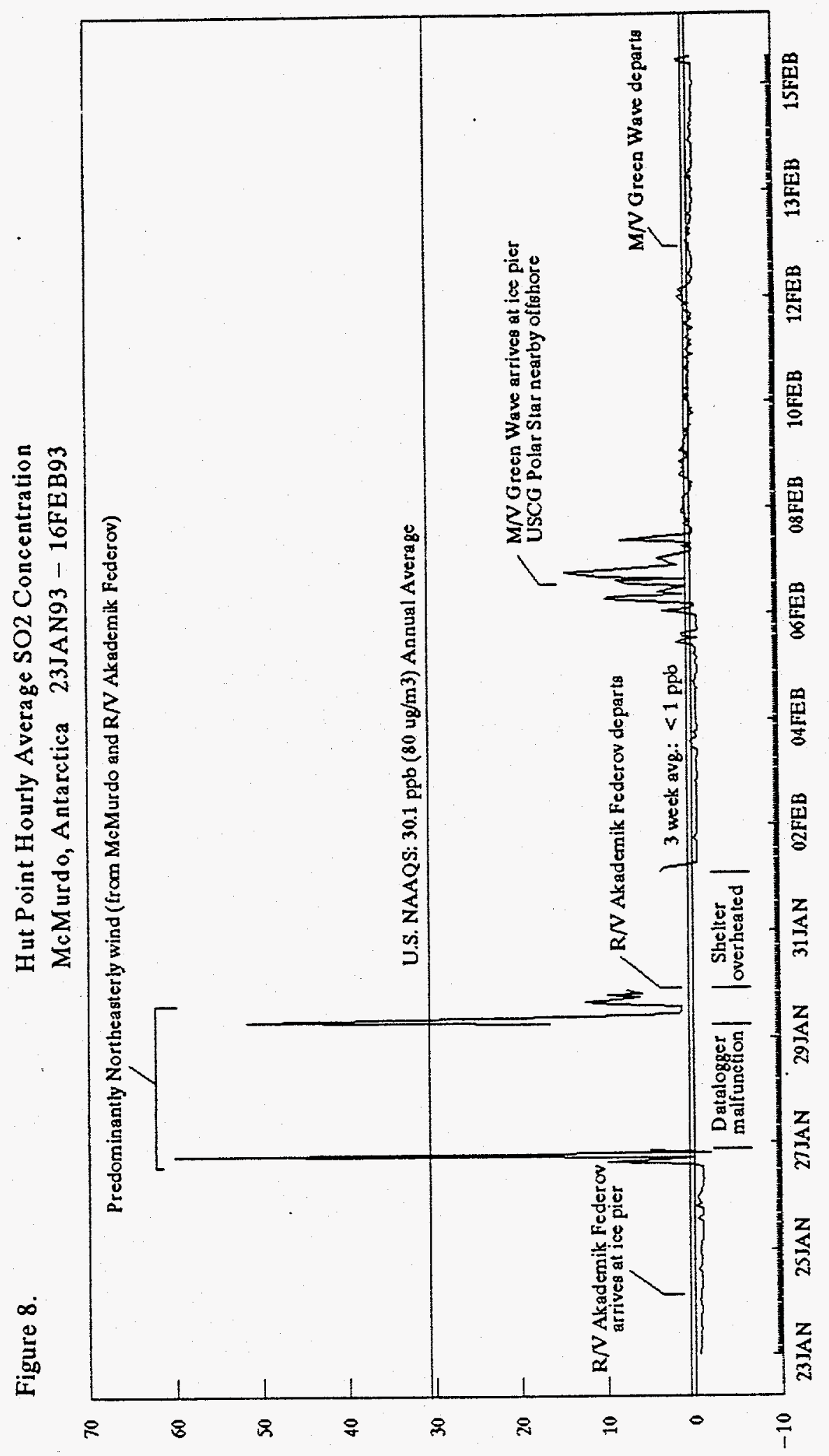

(qdd) עongendasuos zOS 


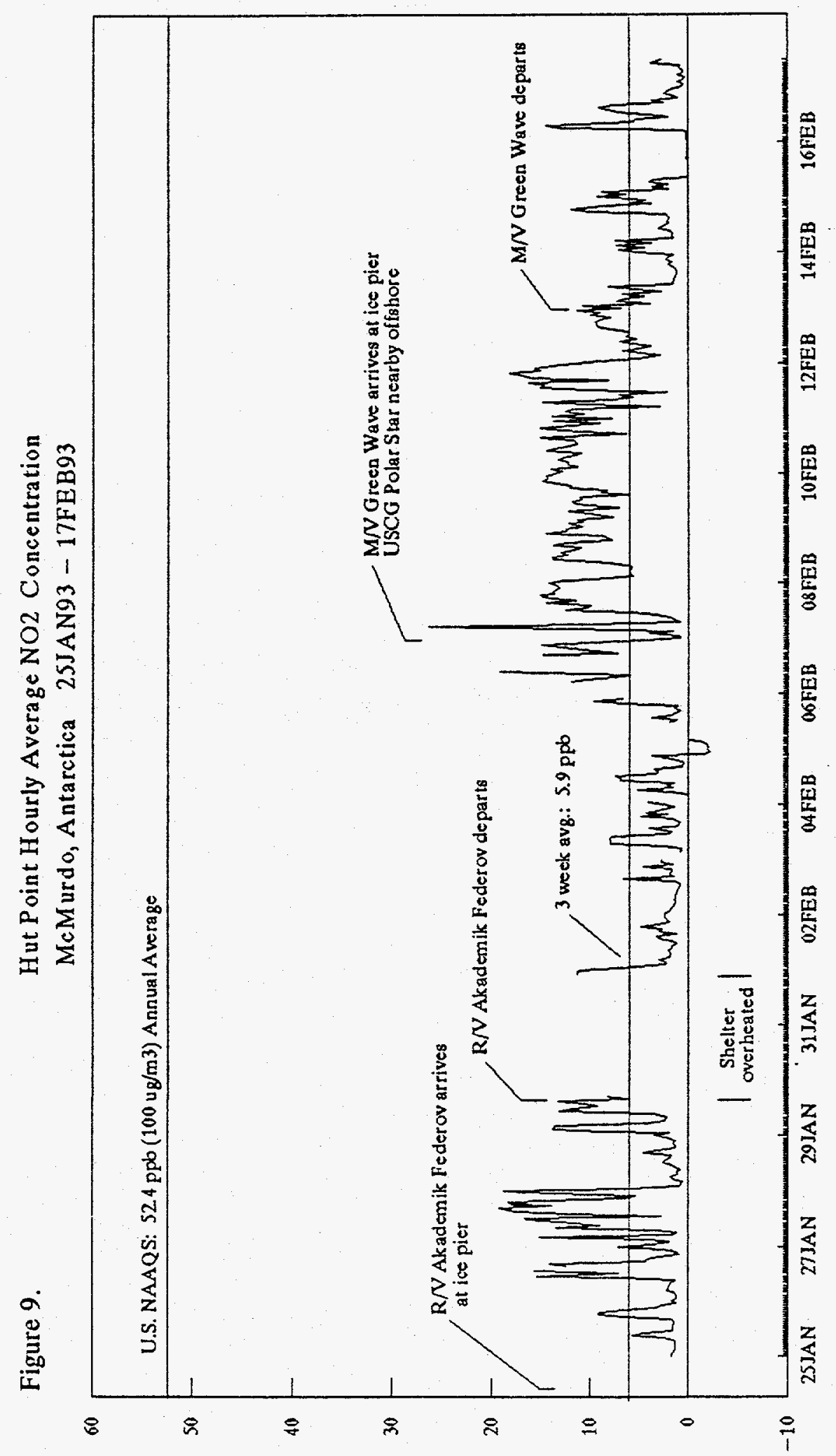

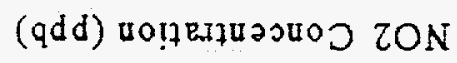




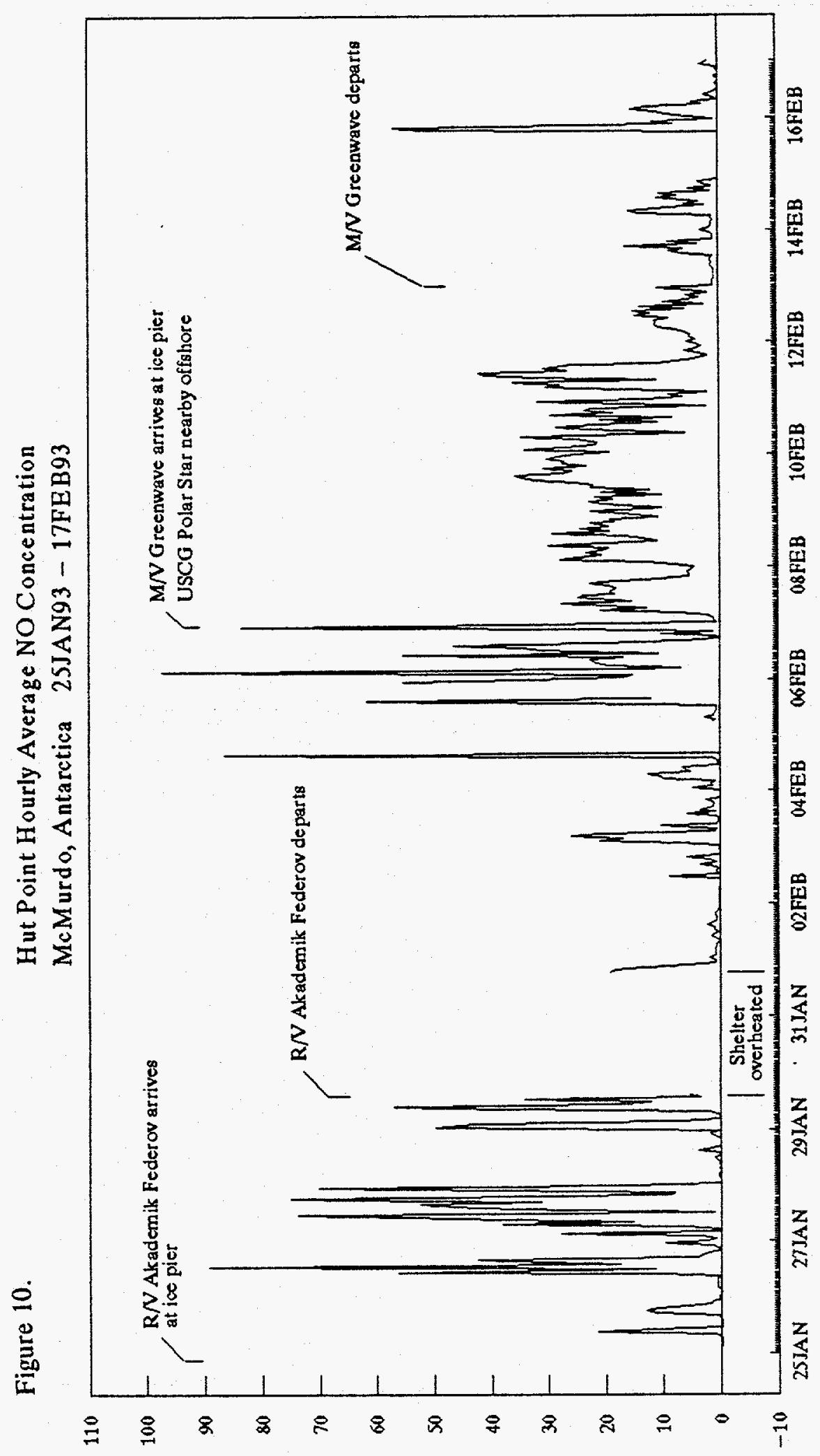

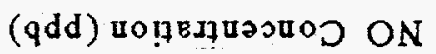




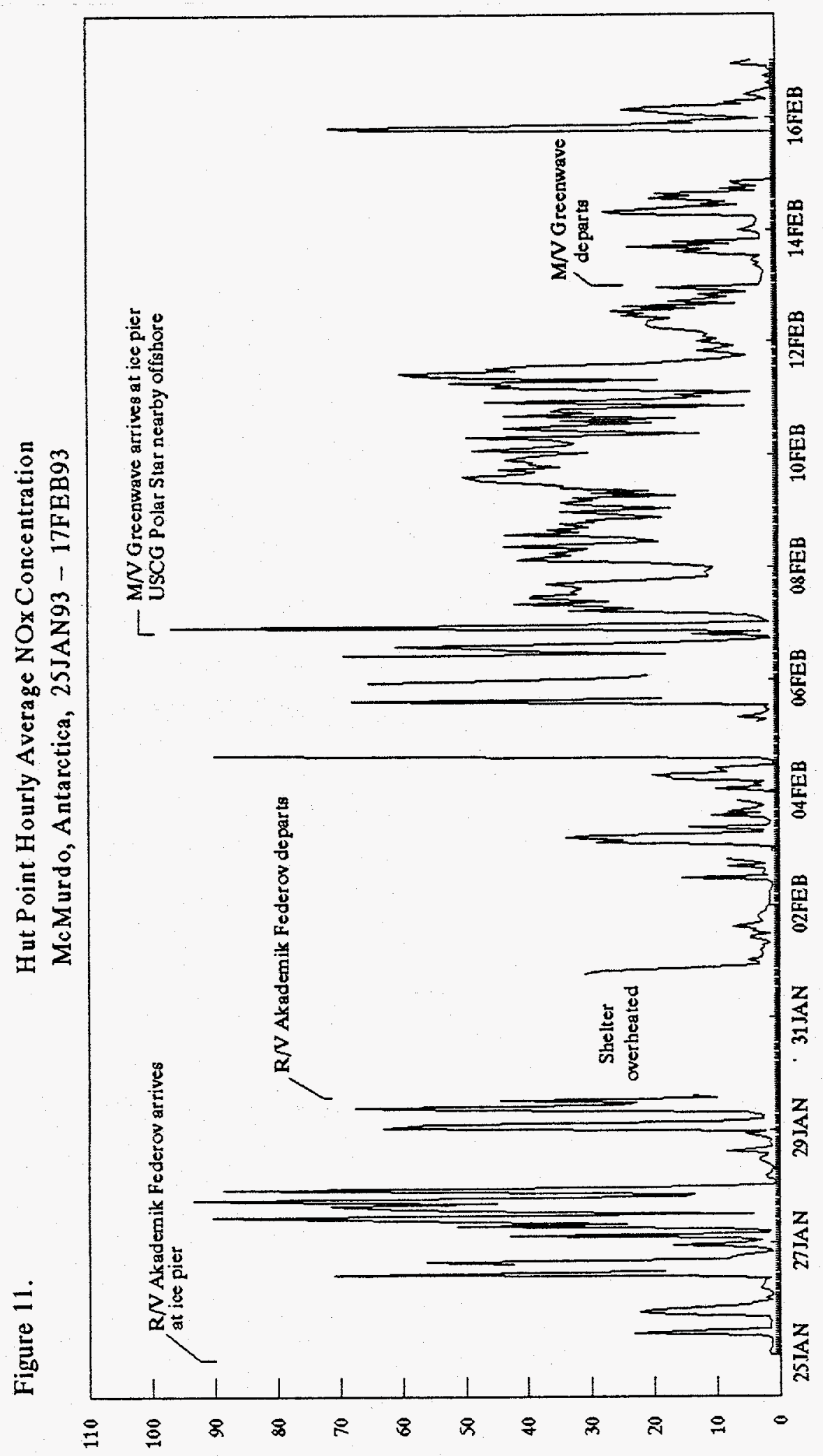

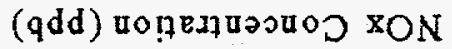


Table 3. Summary of $\mathrm{SO}_{2}, \mathrm{NO}, \mathrm{NO}_{2}, \mathrm{NO}_{\mathbf{x}}$ and $\mathrm{CO}$ Monitoring Results at McMurdo Station, Antarctica

\begin{tabular}{|c|c|c|c|c|c|}
\hline Pollutant & $\begin{array}{l}\quad \text { Central } \\
\text { McMurdo } \\
\text { (2-week avg.) }\end{array}$ & $\begin{array}{c}\text { Hut } \\
\text { Point } \\
\text { (3-week avg.) }\end{array}$ & $\begin{array}{l}\text { U.S. National Air } \\
\text { Quality Standard }\end{array}$ & Background & Urban \\
\hline $\mathrm{SO}_{2}$ & $<1 \mathrm{ppb}$ & $<1 \mathrm{ppb}$ & $\begin{array}{l}\text { Annual Average: } 80 \mu \mathrm{g} / \mathrm{m}^{3} \\
(30.1 \mathrm{ppb}) \\
\text { 24-hr. } \max : 365 \mu \mathrm{g} / \mathrm{m}^{3}(139.3 \\
\text { ppb) } \\
\text { 3-hr. } \max .: 500 \mathrm{ppb} \\
\left(1300 \mu \mathrm{g} / \mathrm{m}^{3}\right)\end{array}$ & $\begin{array}{l}0.2 \mathrm{ppb}^{\mathrm{a}} \\
0.3-1.1 \mathrm{ppb}^{\mathrm{b}} \\
\text { (Antarctica) } \\
0.02-0.2 \mathrm{ppb}^{\mathrm{c}} \\
\text { (Antarctic area) } \\
0.5-1.2 \mathrm{ppb}^{\mathrm{d}} \\
\text { (King George/ } \\
\text { Penguin Islands) }\end{array}$ & $\begin{array}{l}2.7-23 \mathrm{ppb}^{\mathrm{e}} \\
\text { (international) } \\
8.0-12 \mathrm{ppb}^{\mathrm{f}} \\
\text { (U.S) }\end{array}$ \\
\hline $\mathrm{NO}_{2}$ & $4.6 \mathrm{ppb}$ & $5.9 \mathrm{ppb}$ & $\begin{array}{l}\text { Annual Average: } 100 \mu \mathrm{g} / \mathrm{m}^{3} \\
(52.4 \mathrm{ppb})\end{array}$ & $0.5-4.0 \mathrm{ppb}^{\mathrm{a}}$ & $\begin{array}{l}22-28 \mathrm{ppb}^{\mathrm{f}} \\
\text { (U.S.) }\end{array}$ \\
\hline No & $4.7 \mathrm{ppb}$ & $11.0 \mathrm{ppb}$ & None & $0.2-2.0 \mathrm{ppb}^{\mathrm{a}}$ & \\
\hline $\mathrm{NO}_{\mathrm{x}}$ & $9.2 \mathrm{ppb}$ & $16.7 \mathrm{ppb}$ & None & $\begin{array}{l}31 \text { ppb annual mean } \\
@ \text { Syowa Station, } \\
\text { Antarctica }\end{array}$ & $40-80 p^{p b}$ \\
\hline $\mathrm{CO}$ & $0.2 \mathrm{ppm}$ & $<0.1 \mathrm{ppm}$ & $\begin{array}{l}\text { 8-hour avg.: } 10 \mathrm{mg} / \mathrm{m}^{3}(8.6 \\
\text { ppm) } \\
\text { 1-hour max.: } 40 \mathrm{mg} / \mathrm{m}^{3}(34.9 \\
\text { ppm) }\end{array}$ & $\begin{array}{l}100 \mathrm{ppb}^{\mathrm{a}} \\
40-70 \mathrm{ppb} @ \text { South } \\
\text { Pole }\end{array}$ & $\begin{array}{l}1.1-1.6 \mathrm{ppm}^{\mathrm{f}} \\
\text { (U.S.) }\end{array}$ \\
\hline
\end{tabular}

\section{Sources:}
a. Robinson and Robbins 1969
b. Sterns 1976
c. Nguyen Ba Cuong et al. 1974
d. Molski et al. 1981
e. OECD 1991
f. U.S. EPA 1992
g. Wark and Warner 1976
h. Khalil and Rasmussen 1989 
following four-day $\mathrm{NO}_{2}$ average dropped to $2.9 \mathrm{ppb}$. NO, and $\mathrm{NO}_{\mathrm{x}}$ levels responded similarly (See Figures $9,10, \& 11)$. A similar correlation was observed during the period of time the resupply ship, Merchant Vessel (M/V) Greenwave was docked at the ice pier, with $\mathrm{NO}_{2}$ concentrations averaging $10.3 \mathrm{ppb}$ during the six-day ship loading activities; dropping to $3.1 \mathrm{ppb}$ for the 4 days after the M/V Greenwave's departure (See Figures $4,5, \& 6$ ).

Although the gas monitoring data set for the austral summer season was considerably smaller than originally planned, the effort did prove useful in assessing the analyzer and shelter performance, determining the range of pollutant concentrations present, providing information to optimize future analyzer-specific QA/QC requirements, and provided useful data for assessing the impact of McMurdo operations on the local air quality. 


\section{References}

Code of Federal Regulations, 40CFR50, Appendix A, "Reference Method for the Determination of Sulfur Dioxide in the Atmosphere, Office of the Federal Register, July 1991.

Code of Federal Regulations, 40CFR50, Appendix C, "Measurement Principle and Calibration Procedure for the Measurement of Carbon Monoxide in the Atmosphere (Non-dispersive infrared photometry)", Office of the Federal Register, July 1991.

Code of Federal Regulations, 40CFR50, Appendix F, "Measurement Principle and Calibration Procedure for the Measurement of Nitrogen Dioxide in the Atmosphere (Gas Phase Chemiluminescence)", Office of the Federal Register, July 1991.

Code of Federal Regulations, 40CFR58, Appendix D, "Network Design for State and Local Air Monitoring Stations (SLAMS) and National Air Monitoring Stations (NAMS)," Office of the Federal Register, July 1989.

Khalil, M.A.K., and R.A. Rasmussen, 1989. "Seasonal Cycles of Hydrogen and Carbon monoxide in the Polar Regions: Opposite-phase Relationships," Antarctic Journal, 1989 Review.

Lugar, Robert M., 1992. FY-1993 Ambient Air Monitoring Plan for McMurdo Station, Antarctica. Prepared for National Science Foundation Division of Polar Programs. EG\&G Idaho, Idaho Falls, ID 83415-1406. September 1992.

Molski, Boguslaw, Andrzej Bytnerowicz, and Wojciech Dmuchowski 1981. "Air Pollution With Sulfur Dioxide and Fluorine Compounds in the Vicinity of the Arctowski Station, King George Island, South Shetland Islands." Polish Polar Research, 2/1-2/87-93/1981.

National Science Foundation, 1989. Implementation of the National Science Foundation's Strategy for Compliance with Environmental Law in Antarctica. National Science Foundation, Washington, D.C. 19 pp. 1989.

National Science Foundation, 1991. Supplemental Environmental Impact Statement for the United States Antarctic Program. National Science Foundation, Washington, D.C. October 1991.

Nyguyen Ba Cuong, Bernard Bonsang, and Gerard Lambert, 1974. "The Atmospheric Concentration of Sulfur Dioxide and Sulfate Aerosols Over Antarctic, Subantarctic Areas and Oceans." Tellus XXXVI (1974), 1-2.

Organization for Economic Cooperation and Development (OECD), 1991. The State of the Environment. Paris, France, 1991.

Pearson, C.V., 1991. Technology Assessment: Evaluation and Design of a High Temperature Incinerator for Treatment of Solid Wastes at McMurdo Station, Ross Island, Antarctica. Part II: Reference System Description for the Interim Incinerator Facility. Argonne National Laboratory, Argonne, IL. June 1991. 
Robinson, E. and R.C.Robbins, 1969. "Sources, Abundances, and Fate of Atmospheric Pollutants." Stanford Research Institute, Report SRI Project PR-6755, February 1968. Supplemental Report, June 1969.

Sterns, A.S. (Ed.) 1976. Air Pollution. Academic Press, New York, San Francisco, London, 684 pp. 1976.

United States Environmental Protection Agency, 1977. Quality Assurance Handbook for Air Pollution Measurement Systems, Volume II - Ambient Air Specific Methods. Research Triangle Park, NC. EPA-600/4-77-027a, May 1977.

United States Environmental Protection Agency, 1992. National Air Quality Trends and Emissions Trends Report, 1991. U.S. EPA Office of Air Quality Planning and Standards, Research Triangle Park, NC. 450-R-92-001, October 1992.

Wark, Kenneth, and Cecil F. Warner, 1976. Air Pollution, Its Origin and Control. Harper \& Row Publishers, New York, New York. 1976. 